\title{
The effect of temperature on the initial development of Brycon amazonicus Spix \& Agassiz, 1829 as tool for micromanipulation of embryos
}

\author{
Regiane Cristina da Silva ${ }^{1}$, Matheus Pereira dos Santos ${ }^{2}$, José Augusto Senhorini ${ }^{3}$, \\ Maria do Carmo Faria Paes ${ }^{4}$, Fernanda Nogueira Valentin ${ }^{2}$, Takafumi Fujimoto ${ }^{5}$, \\ Nivaldo Ferreira do Nascimento ${ }^{2}$, George Shigueki Yasui ${ }^{3}$ and Laura Satiko Okada Nakaghi ${ }^{2,4}$ \\ UNESP's Aquaculture Centre, Jaboticabal, Brazil; Fish Biotechnology Laboratory, National Centre for Research and \\ Continental Fish Conservation, CEPTA/ICMBio, Pirassununga, Brazil; Laboratory Animal Histology and Embryology, \\ Department of Animal Morphology and Physiology, UNESP, Jaboticabal, Brazil; and Faculty of Fisheries Sciences, Hokkaido \\ University, Hakodate, Japan
}

Date submitted: 13.07.2017. Date accepted: 22.07.2017

\section{Summary}

Primordial germ cell (PGC) transplant is a promising tool in aquaculture; however, successful use of this technique requires in depth knowledge of the early stages of embryo and larval development. The aim of this study was to analyse the effect of different temperatures $\left(22,26\right.$, and $\left.30^{\circ} \mathrm{C}\right)$ on the early development of $B$. amazonicus. The newly fertilized eggs were distributed into tanks with controlled temperature and oxygenation. Samples were collected at pre-established times and analysed under light and fluorescence microscopy. Temperature influenced the speed and duration of each stage of early development, including hatching time. The highest pronuclei fusion rate was observed $8 \mathrm{~min}$ post-fertilization (mpf) at 22 and $26^{\circ} \mathrm{C}$, and $6 \mathrm{mpf}$ at $30^{\circ} \mathrm{C}$. The duration of the $512-1000$ blastomeres phase during in the blastocyst stage was $1 \mathrm{~h} 30 \mathrm{~min}$ at $22^{\circ} \mathrm{C}$, and $25 \mathrm{~min}$ at 26 and $30^{\circ} \mathrm{C}$. Hatching occurred at $24 \mathrm{~h} 30 \mathrm{mpf}$ at $22^{\circ} \mathrm{C}, 16 \mathrm{~h}$ post-fertilization (hpf) at $26^{\circ} \mathrm{C}$, and $11 \mathrm{~h} 30 \mathrm{mpf}$ at $30^{\circ} \mathrm{C}$. The rate of morphologically normal larvae was $88.34 \%$ at $22^{\circ} \mathrm{C}, 90.49 \%$ at $26^{\circ} \mathrm{C}$, and $73 \%$ at $30^{\circ} \mathrm{C}$. Malformations of the head, yolk sac, heart, and tail were observed in all temperatures. Nevertheless, B. amazonicus embryos were able to develop satisfactory in all three temperatures tested. These results enable embryo manipulation at different temperatures to optimize the micromanipulation time of embryos and larvae for biotechnological studies.

Keywords: Blastula, Cell transplantation, Chimera, Embryo, Germ cell

\footnotetext{
${ }^{1}$ All correspondence to: Regiane Cristina da Silva. UNESP's Aquaculture Centre (CAUNESP), UNESP - São Paulo State University, Campus Jaboticabal-SP. Via de Acesso Prof. Paulo Donato Castellane s/n, CEP 14884-900, Jaboticabal, SP Brazil. E-mail: regianesilva_bio@yahoo.com.br

${ }^{2}$ UNESP's Aquaculture Centre (CAUNESP), UNESP - São Paulo State University, Campus Jaboticabal-SP. Via de Acesso Prof. Paulo Donato Castellane s/n, CEP 14884-900, Jaboticabal, SP, Brazil.

${ }^{3}$ Fish Biotechnology Laboratory, National Centre for Research and Continental Fish Conservation, Chico Mendes Institute of Biodiversity Conservation (CEPTA/ICMBio), Rodovia Pref. Euberto Nemesio Pereira de Godoy, Km 6,5, CEP 13630-970. Pirassununga-SP, Brazil.

${ }^{4}$ Laboratory Animal Histology and Embryology, Department of Animal Morphology and Physiology, UNESP- São Paulo
}

\section{Introduction}

The genus Brycon comprises more than 60 fish species, 40 of which can be found in Central and South America (Howes, 1982), from the South of Mexico to Argentina and from the rivers of the Pacific coast to Colombia, Ecuador, and Peru (Lima and Castro, 2000); in which members of the genus Brycon are a source of food and of great importance to the aquaculture market.

\footnotetext{
State University, Campus Jaboticabal-SP. Via de Acesso Prof. Paulo Donato Castellane s/n, CEP 14884-900 Jaboticabal, SP, Brazil.

${ }^{5}$ Faculty of Fisheries Sciences, Hokkaido University, 3-1-1 Minato-cho, 041-8611 Hakodate, Japan.
} 
Brycon amazonicus, Characidae (Spix \& Agassiz, 1829) is among the many species of this genus with great aquaculture potential. In Brazil, it can be found in the Amazon River and its tributaries (Camargo et al., 2008), being the second most farmed species in the Amazon region. This fish is a reophilic species, with breeding period between September and February; consequently, the production of fry is restricted to a few months of the year (Gomes \& Urbinati, 2005).

Primordial germ cells transplant aimed at chimera production is a technique of great importance in the preservation, regeneration, and even large scale fish production (Nakagawa et al., 2002). However, the first step in applying this cell transplant technique is to understand the embryonic and larval development of the target species, with detailed description to aid embryo manipulation (Fujimoto et al., 2006), in which temperature is a major differential (Nakauth et al., 2015).

Adequate temperature manipulation during early development enables embryos from the same spawn, but at different phases of development, to be cultured at the same time without compromising their viability (Kimmel et al., 1995). Besides that, the embryonic development of Teleostei is influenced by environmental conditions, especially temperature, which is an essential physical regulator factor on the lives of fish as it affects several physiological processes, such as the duration of embryonic and larval development, hatching time, and survival rate (Pankhurst \& Munday, 2011; Nakaghi et al., 2013; Uji et al., 2014). This approach, associated with chromosome manipulation, transgenesis, cell transplant, and genetic bank of PGCs, helps towards meeting the growing demands for uninterrupted animal protein of aquacultural origin; increases genetic diversity (Melamed et al., 2002); and provides resources for species of the same genus in danger of extinction, thus preserving biodiversity.

Therefore, adequate temperature manipulation can be useful in prolonging the embryonic phases and optimizing the micromanipulation time of embryos kept at different temperatures, as well as identifying the best temperature to culture embryos without affecting their normal development. Thus, the aim of this study was to analyse the effect of three incubation temperatures $\left(22,26\right.$, and $\left.30^{\circ} \mathrm{C}\right)$ on the early development of $B$. amazonicus.

\section{Materials and Methods}

\section{Broodstock and induced breeding}

The experimental study took place at the National Centre for Research and Continental Fish Conservation, Chico Mendes Institute of Biodiversity
Conservation (CEPTA/ICMBio), PirassunungaSP, Brazil; and the analysis performed at the Fish Biotechnology Laboratory (CEPTA/ICMBio).

Brycon amazonicus broodstock were kept in 1000 $\mathrm{m}^{2}$ tanks, at stock density of $150 \mathrm{~g} / \mathrm{m}^{2}$. Commercial feed containing $35 \%$ crude protein was provided three times a week until apparent satiation. Broodstock were selected for hormonal induction based on secondary sexual maturation characteristics; such as distended abdomen and red urogenital papilla in females, and semen release following gentle cephalo-caudal pressure of the coelomic cavity in males. The selected broodstock (six couples) were kept in $3.0 \times 1.0$ $\mathrm{m}$ rectangular masonry tanks of $0.8 \mathrm{~m}$ depth with constant water flow at $29.0 \pm 2.0^{\circ} \mathrm{C}$.

Hormonal induction was carried out using macerated common carp Cyprinus carpio crude hypophysis extract (CHE) diluted in saline solution $(0.9 \%)$, which was applied at the base of the pectoral fin. Females received two doses of $\mathrm{CHE}, 0.5 \mathrm{mg} \mathrm{kg}^{-1} \mathrm{CHE}$ as first and $5.0 \mathrm{mg} \mathrm{kg}^{-1}$ as the second dose, while the males received a single dose of $1.0 \mathrm{mg} / \mathrm{kg}^{-1} \mathrm{CHE}$ concomitantly to the females' second dose. Only one couple out of six did not spawn. The spawning couples were used in the study of early development (three couples) and in embryo quantification at the main stages of development (five couples). Each couple was considered as a repetition for the three temperatures analysed.

Once the effects of the hormone wore off (6 to $8 \mathrm{~h})$, the males and females were transferred to plastic containers filled with menthol anaesthetic $(\sim 100 \mathrm{mg}$ $1^{-1}$, Êxodo Científica, Brazil) and submerged for 2 to $4 \mathrm{~min}$. Subsequent to anaesthesia, the gametes were extruded by gentle cranial-caudal massage of the coelomic cavity.

\section{Samples and sampling times}

After extrusion, an aliquot of $\sim 50$ oocytes was collected and fixed in $2 \%$ glutaraldehyde solution containing phosphate-buffered saline (D-PBS; Dulbecco's phosphate-buffered saline, D-5773, Sigma ${ }^{\circledR}$, USA) and the remaining oocytes fertilized by the dry method. A sample of the eggs was collected at the time of fertilization (time zero) and the remaining eggs distributed into three 40 litre tanks with continuous oxygenation and controlled temperatures at 22, 26, and $30^{\circ} \mathrm{C}$. Samples from each treatment were collected every $2 \mathrm{~min}$ up to $10 \mathrm{~min}$ post-fertilization (mpf), then every 5 min until hatching, and subsequently every 15 min up to $25 \mathrm{~h}$ post-fertilization (hpf). The experiment for the study of early development in B. amazonicus was performed in triplicate, in which each couple was considered a replicate. During the gastrula stage, the water from the tanks was replaced with previously 
acclimatized water at the corresponding temperatures to ensure good water quality throughout the study period.

Dissolved oxygen and $\mathrm{pH}$ levels were recorded during early development using a YSI 550A multiparameter equipment (YSI Inc, USA). Dissolved oxygen levels were $67 \%\left(22^{\circ} \mathrm{C}\right), 58 \%\left(26^{\circ} \mathrm{C}\right)$, and $61 \%\left(30^{\circ} \mathrm{C}\right)$; and mean $\mathrm{pH}$ was $7.0 \pm 0.22$.

For each temperature, a small aliquot of $\sim 60$ eggs was sampled and kept under the same conditions in order to determine the survival rate during the different stages of embryo development, as well as the rates of normal and abnormal larvae. Five repetitions were used for quantification, with each couple representing one repetition.

\section{Visualization of the pronucleus}

The visualization of pronuclei fusion (karyogamy) at each temperature tested was preceded by the mechanical removal of the chorion of 20 eggs fixed in $2 \%$ glutaraldehyde containing phosphate-buffered saline (D-PBS) with the aid of two tweezers at $2,4,6,8$, or $10 \mathrm{mpf}$. The eggs were kept for 5 min in a staining solution containing $60 \mu \mathrm{l} 4^{\prime}, 6-$ diamidino-2-fenilindole di-hydrochloride fluorescent dye (DAPI, D-9542, Sigma ${ }^{\circledR}$, USA) and $10 \mathrm{~mL}$ DPBS (D-5773, Sigma ${ }^{\circledR}$, USA), prepared according to the manufacturer's recommendation. The eggs were analysed using a fluorescence microscope (Nikon Eclipse $\mathrm{Ni}$, Japan) equipped with ultraviolet (UV) filter. In order for the events taking place to be analysed, the pronuclei were classified as: not fused (individual pronuclei with one of them proximal to the egg's margin), adjacent (pronuclei in the centre of the egg), fused (only one visible pronucleus, evidently larger), or absent/not observed (when neither of the pronuclei could be seen).

\section{Classification of the early development in Brycon amazonicus}

The term 'oocyte' refers to the feminine gamete before fertilization; 'egg' comprises the stages immediately after fertilization until the end of the gastrula stage, when there was the development of the embryonic axis; after which the term 'embryo' is used. The term 'larvae' was used after the rupture of the chorion at the time of hatching until complete yolk absorption (Faustino et al., 2010).

The stages of the early development in Brycon amazonicus were determined when $50 \%$ of the fixed samples were found to be at the same stage of development. The method used to classify the stages was adapted from zebrafish by Kimmel et al. (1995) and from loach by Fujimoto et al. (2006, 2004). Thus, the early development of $B$. amazonicus was divided into: zygote (egg formed by a single cell); cleavage (2-64 cells); early blastula (cleavage of 128 , 256,512 , or $1000+$ cells), mid blastula (elongating phase), and late blastula (spherical and cupule phase, $30 \%$ epiboly); gastrula (50\% epiboly until blastopore closure); segmentation (differentiation of the head and tail and development of somites); and hatching (rupture of the chorion by the larva).

\section{Morphometric analysis}

The external morphometry of the oocytes, eggs, embryos, and larvae was analysed under light microscopy (Nikon, SMZ 1500, Tokyo, Japan) and digital images obtained with a charged coupled device (CCD) camera (Nikon, DS-Fi, Japan) and NIS-AR Elements software (Nikon, Tokyo, Japan). The size (width and height) of the embryos at the different temperatures was measured in millimetres ( $\mathrm{mm})$ when these had two cells (cleavage), 1024 cells (blastula), 50\% epiboly (gastrula), and 10 somites (segmentation). Height was considered as the distance between the animal and vegetal pole, and width as the perpendicular axis that crossed the height axis at the middle. Larvae total length was recorded at hatching.

\section{Statistical analysis}

Data are expressed as mean \pm standard error (SE). Data were analysed using the General Linear Models (GLM) of the software SAS (SAS 9.1, SAS Institute, Cary. NC, USA) and subjected to analysis of variance [analysis of variance (ANOVA)]. Means that were significantly different were compared by the Tukey test. Significance was considered at $P<0.05$.

\section{Results}

The controlled incubation temperatures of 22, 26, and $30^{\circ} \mathrm{C}$ influenced embryo and larval development times, with morphological events occurring faster at $30^{\circ} \mathrm{C}$ and slower at $22^{\circ} \mathrm{C}$. The characteristics of each stage of the early development and their respective time of occurrence are detailed in Table 1 (stages of embryo development, from fertilization to hatching) and Table 2 (larval development, after hatching).

\section{Zygote}

The effects of temperature could be seen in newly fertilized eggs analysed under fluorescence microscopy, in which the fusion of the two haploid pronuclei (Fig. $1 a, b$ ), one of maternal and the other of paternal origin, generated a single nucleus, the zygote (Fig. 1c). This event, denominated karyogamy, occurred in the central region of the eggs a few min after gamete 
Table 1 Time of occurrence of the morphological events at the different stages of embryonic development in B. amazonicus incubated at 22,26 , or $30^{\circ} \mathrm{C}$

\begin{tabular}{|c|c|c|c|c|}
\hline \multirow{2}{*}{$\begin{array}{l}\text { Stage of } \\
\text { development }\end{array}$} & \multirow[b]{2}{*}{ Morphological events } & \multicolumn{3}{|c|}{ Incubation temperature } \\
\hline & & $22^{\circ} \mathrm{C}$ & $26^{\circ} \mathrm{C}$ & $30^{\circ} \mathrm{C}$ \\
\hline Zygote & Formation of the animal pole ( 1 cell) & $25 \min$ & $20 \mathrm{~min}$ & $15 \mathrm{~min}$ \\
\hline \multirow[t]{6}{*}{ Cleavage } & 2-cell & $1 \mathrm{~h}$ & $40 \mathrm{~min}$ & $25 \mathrm{~min}$ \\
\hline & 4-cell & $1 \mathrm{~h} 10 \mathrm{~min}$ & $50 \mathrm{~min}$ & $35 \mathrm{~min}$ \\
\hline & 8-cell & $1 \mathrm{~h} 30 \mathrm{~min}$ & $1 \mathrm{~h}$ & $40 \mathrm{~min}$ \\
\hline & 16-cell & $1 \mathrm{~h} 45 \mathrm{~min}$ & $1 \mathrm{~h} 10 \mathrm{~min}$ & $50 \mathrm{~min}$ \\
\hline & 32-cell & $2 \mathrm{~h}$ & $1 \mathrm{~h} 20 \mathrm{~min}$ & $1 \mathrm{~h}$ \\
\hline & 64-cell & $2 \mathrm{~h} 15 \mathrm{~min}$ & $1 \mathrm{~h} 30 \mathrm{~min}$ & $1 \mathrm{~h} 10 \mathrm{~min}$ \\
\hline \multirow[t]{8}{*}{ Blastula } & 128-cell & $2 \mathrm{~h} 30 \mathrm{~min}$ & $1 \mathrm{~h} 45 \mathrm{~min}$ & $1 \mathrm{~h} 20 \mathrm{~min}$ \\
\hline & 256-cell & $2 \mathrm{~h} 45 \mathrm{~min}$ & $1 \mathrm{~h} 55 \mathrm{~min}$ & $1 \mathrm{~h} 40 \mathrm{~min}$ \\
\hline & 512-cell & $3 \mathrm{~h}$ & $2 \mathrm{~h} 10 \mathrm{~min}$ & $1 \mathrm{~h} 55 \mathrm{~min}$ \\
\hline & 1000-cell & $3 \mathrm{~h} 30 \mathrm{~min}$ & $2 \mathrm{~h} 25 \mathrm{~min}$ & $2 \mathrm{~h} 10 \mathrm{~min}$ \\
\hline & Oblong & $4 \mathrm{~h} 30 \mathrm{~min}$ & $2 \mathrm{~h} 35 \mathrm{~min}$ & $2 \mathrm{~h} 30 \mathrm{~min}$ \\
\hline & Spherical & $5 \mathrm{~h} 20 \mathrm{~min}$ & $2 \mathrm{~h} 40 \mathrm{~min}$ & $2 \mathrm{~h} 40 \mathrm{~min}$ \\
\hline & Dome & $6 \mathrm{~h} 30 \mathrm{~min}$ & 2 h 50 min & $2 \mathrm{~h} 50 \mathrm{~min}$ \\
\hline & $30 \%$ epiboly & $7 \mathrm{~h}$ & $3 \mathrm{~h}$ & $3 \mathrm{~h} 05 \mathrm{~min}$ \\
\hline \multirow[t]{3}{*}{ Gastrula } & $50 \%$ epiboly & $7 \mathrm{~h} 30 \mathrm{~min}$ & $4 \mathrm{~h}$ & $3 \mathrm{~h} 10 \mathrm{~min}$ \\
\hline & $90 \%$ epiboly & $10 \mathrm{~h}$ & & $4 \mathrm{~h} 30 \mathrm{~min}$ \\
\hline & $\begin{array}{l}100 \% \text { epiboly - differentiation of the } \\
\text { cephalic and caudal regions }\end{array}$ & $11 \mathrm{~h} 30 \mathrm{~min}$ & $7 \mathrm{~h} 15 \mathrm{~min}$ & $5 \mathrm{~h} 30 \mathrm{~min}$ \\
\hline \multirow[t]{9}{*}{$\begin{array}{l}\text { Segmentation } \\
\text { (organogenesis) }\end{array}$} & Appearance of the first somites & $12 \mathrm{~h} 30 \mathrm{~min}$ & $8 \mathrm{~h}$ & $5 \mathrm{~h} 45 \mathrm{~min}$ \\
\hline & $\begin{array}{l}10 \text { somites - development of the optic } \\
\text { vesicle }\end{array}$ & $14 \mathrm{~h} 30 \mathrm{~min}$ & $9 \mathrm{~h} 30 \mathrm{~min}$ & $6 \mathrm{~h} 45 \mathrm{~min}$ \\
\hline & 12 somites & $15 \mathrm{~h} 30 \mathrm{~min}$ & $10 \mathrm{~h}$ & $7 \mathrm{~h}$ \\
\hline & $14 / 16$ somites & $16 \mathrm{~h}$ & $10 \mathrm{~h} 15 \mathrm{~min}$ & $7 \mathrm{~h} 15 \mathrm{~min}$ \\
\hline & $\begin{array}{l}18 \text { somites - development of the otic } \\
\text { vesicle and yolk extension }\end{array}$ & $17 \mathrm{~h} 30 \mathrm{~min}$ & $11 \mathrm{~h}$ & $7 \mathrm{~h} 45 \mathrm{~min}$ \\
\hline & $\begin{array}{l}20 \text { somites - development of the Kupffer } \\
\text { vesicle }\end{array}$ & $18 \mathrm{~h} 30 \mathrm{~min}$ & $11 \mathrm{~h} 30 \mathrm{~min}$ & $8 \mathrm{~h}$ \\
\hline & $\begin{array}{l}22 \text { somites - embryo elongation by the } \\
\text { cephalo-caudal axis }\end{array}$ & $19 \mathrm{~h} 30 \mathrm{~min}$ & $12 \mathrm{~h}$ & $8 \mathrm{~h} 30 \mathrm{~min}$ \\
\hline & $\begin{array}{l}28 \text { somites - evident yolk extension and } \\
\text { start of pericardial cavity development }\end{array}$ & $21 \mathrm{~h}$ & $13 \mathrm{~h} 30 \mathrm{~min}$ & $9 \mathrm{~h} 15 \mathrm{~min}$ \\
\hline & $\begin{array}{l}30 \text { somites - start of the central nervous } \\
\text { system development }\end{array}$ & $22 \mathrm{~h} 30 \mathrm{~min}$ & $13 \mathrm{~h} 45 \mathrm{~min}$ & $9 \mathrm{~h} 30 \mathrm{~min}$ \\
\hline Hatching & $\begin{array}{l}\text { Rupture of the chorion and distended } \\
\text { posture }\end{array}$ & 24 h 30 min & $16 \mathrm{~h}$ & $11 \mathrm{~h} 30 \mathrm{~min}$ \\
\hline
\end{tabular}

The time when the morphologic events took place was determined when $50 \%$ of the fixed samples were at the same stage of development.

activation, and was observed with greater frequency at $6 \mathrm{mpf}\left(30^{\circ} \mathrm{C}\right)$ and $8 \mathrm{mpf}\left(22\right.$ and $\left.26^{\circ} \mathrm{C}\right)$, as illustrated in Fig. 2.

This stage, culminated with the development of the animal pole, forming the blastodisc composed of cytoplasm and nuclei, and the vegetal pole constituted by the yolk.

Soon after fertilization, the eggs were round, measuring $1.14 \pm 0.07 \mathrm{~mm}$ diameter, and surrounded by a translucent membrane denominated chorion. The hydrated eggs showed perivitelline space and could be classified as telolecithal, due to the great quantity of yolk concentrated at the vegetal pole while the cytoplasm was concentrated at the animal pole (Fig. 3a).

The time required for the development of the animal pole varied according to the incubation temperature and was observed $15 \mathrm{mpf}$ in eggs kept at $30^{\circ} \mathrm{C}, 20 \mathrm{mpf}$ at $26^{\circ} \mathrm{C}$, and $25 \mathrm{mpf}$ at $22^{\circ} \mathrm{C}$.

\section{Cleavage}

Cleavage was meroblastic, occurring only at the animal pole. This stage began when the embryonic 
Table 2 Time of occurrence of the morphological events and hatching in B. amazonicus incubated at $22^{\circ} \mathrm{C}, 26^{\circ} \mathrm{C}$, and $30^{\circ} \mathrm{C}$

\begin{tabular}{|c|c|c|c|}
\hline \multirow{2}{*}{$\begin{array}{l}\text { Time of occurrence } \\
\text { in } \operatorname{hpf}^{a}\end{array}$} & \multicolumn{3}{|c|}{ Incubation temperature } \\
\hline & $22^{\circ} \mathrm{C}$ & $26^{\circ} \mathrm{C}$ & $30^{\circ} \mathrm{C}$ \\
\hline $11 \mathrm{~h} 30 \mathrm{~min}$ & $100 \%$ epiboly & 20 somites & Hatching \\
\hline $14 \mathrm{~h}$ & 8 somites & 30 somites & $\begin{array}{l}\text { Development of CNS. Early pigmentation of } \\
\text { the eyes. Anal opening. Large pericardial } \\
\text { cavity. Visible primitive heart (cardiac tube) }\end{array}$ \\
\hline $16 \mathrm{~h}$ & $14-16$ somites & Hatching & $\begin{array}{l}\text { Increase in the pigmentation of the eyes in the } \\
\text { optical cup. Beginning of mouth } \\
\text { development }\end{array}$ \\
\hline $18 \mathrm{~h}$ & 18 somites & $\begin{array}{l}\text { Development of CNS. } \\
\text { Early pigmentation of the } \\
\text { eyes }\end{array}$ & $\begin{array}{l}\text { Head at semi-ventral position. Differentiation } \\
\text { of the CNS regions }\end{array}$ \\
\hline $22 \mathrm{~h}$ & 28-30 somites & $\begin{array}{l}\text { Beginning of mouth } \\
\text { development. Head at } \\
\text { semi-ventral position }\end{array}$ & $\begin{array}{l}\text { Open mouth. Two cardiac chambers and blood } \\
\text { containing haemoglobin. Outline of branchial } \\
\text { arches. Head at terminal position }\end{array}$ \\
\hline $24 \mathrm{~h} 30 \mathrm{~min}$ & Hatching & Development of lips & $\begin{array}{l}\text { Yolk sac reduction. Start of pectoral fin } \\
\text { development }\end{array}$ \\
\hline
\end{tabular}

The time when the morphologic events took place was determined when $50 \%$ of the fixed samples were at the same stage of development.

${ }^{\mathrm{a}} \mathrm{hpf}=\mathrm{h}$ post-fertilization.
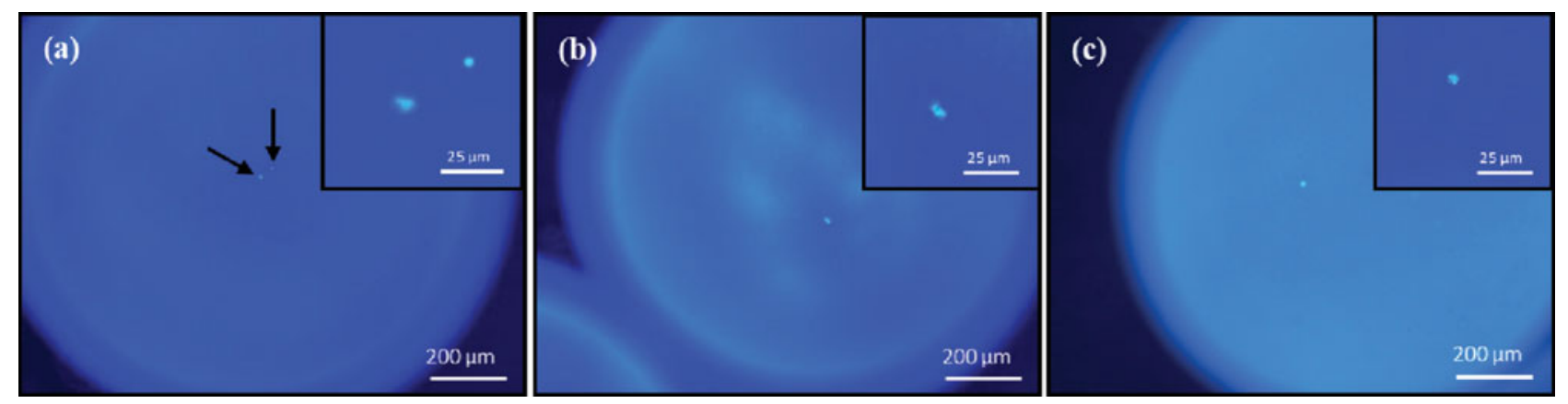

Figure 1 Photomicrographs of newly fertilized eggs of Brycon amazonicus stained with DAPI and observed by fluorescence microscopy. (a) Adjacent pronuclei (arrows). (b) Fusing pronuclei at the centre of the egg. (c) Pronucleus after fusion (fused pronuclei).

cell divided in a vertical plane, forming two identical blastomeres (Fig. 3b) that subsequently divided into four blastomeres of similar sizes across two planes, following a $2 \times 2$ pattern (Fig. $3 c$ ). These four blastomeres also divided vertically and formed eight blastomeres in a $4 \times 2$ pattern (Fig. $3 d$ ), which in turn divided into 16 similar sized blastomeres following a $4 \times 4$ pattern (Fig. 3e), and thus successively (Fig. 3f), until 64 cells were present (Fig. 4g). A reduction in the size of the blastomeres was evident after each mitotic division.

The time of the first cleavage and the interval between the cell divisions varied between the temperatures, demonstrating asynchrony in embryonic development when embryos were subjected to different temperatures (Table 1). Fertilization rate was determined after the first cleavage and was superior to $90 \%$ in all three temperatures (Table 3).

\section{Blastula}

The continuous cell divisions that began during cleavage originated the blastoderm, which characterizes the blastula stage. At the early blastula, there were irregular extracellular spaces on the blastoderm, enabling the visualization of the blastomeres (Fig. 3h) that continued to divide, reaching 256 (Fig. 3i) and later 512 blastomeres (Fig. 3j). At the 10th cleavage, more than 1000 blastomeres formed a highly compacted and small cell mass (Fig. 3k). The time required to reach the stages of 512-1000 blastomeres (phases of interest in cell transplant), as well as the duration of these phases, varied with temperature $\left(1 \mathrm{~h} 30 \mathrm{~min}\right.$ at $22^{\circ} \mathrm{C}$, and $25 \mathrm{~min}$ at $26^{\circ} \mathrm{C}$ and $30^{\circ} \mathrm{C}$ ) as detailed in Table 1.

During mid blastula, at the elongation period that marks the transition between early and late 


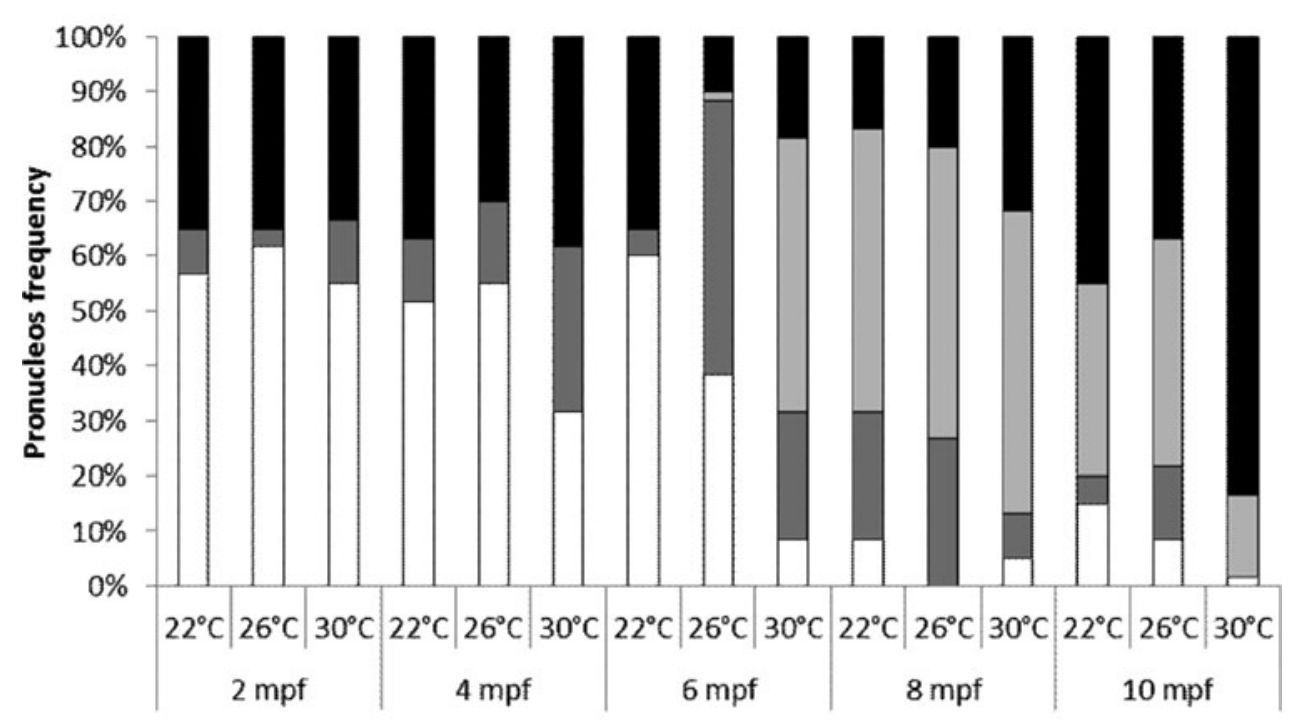

Treatments

$\square$ unfused $\square$ adjacent $\square$ fused $\square$ not seen

Figure 2 Frequency of visualization of the pronuclei in eggs of Brycon amazonicus incubated at 22,26 , and $30^{\circ} \mathrm{C}$ at different times post-fertilization. ${ }^{*} \mathrm{mpf}$, min post-fertilization. $(n=20)$.

blastula, several overlapping layers containing small blastomeres were observed, attributing an ellipsoid form to the blastoderm (Fig. 3l). At this stage, the yolk syncytial layer was formed and the divergence movements of the cells from the animal to the vegetal pole began (epiboly movement). As a consequence, the elongated egg became flat, as illustrated in Fig. 5.

In late blastula, during the spherical phase, the flattening event became very evident and gave the egg and elliptical shape (Fig. $3 m$ ) and posteriorly that of a cupule (Fig. 3n). The epiboly movement was continuous and covered approximately $30 \%$ of the yolk (Fig. 3o), which characterized the end of this stage.

During the blastula stage, egg survival rate was higher than $85 \%$ in all three temperatures (Table 3).

\section{Gastrula}

Gastrula began when the blastoderm covered 50\% of the yolk (Fig. 3p) and was characterized by the movement of endodermic and mesodermic cells to a deep layer of the blastoderm (involution). Gastrula began at different times for each temperature and lasted longest at $22^{\circ} \mathrm{C}$, as illustrated in Table 1 .

At this stage, the embryos showed gradual increase in height while there was a slight reduction in width (Fig. 5) due to the pressure of the cells over the yolk (vegetal pole) during the epiboly movement. The movements of convergence and cell involution of the blastoderm originated the germ ring (Fig. 3q) and the progressive epiboly movements formed the embryonic shield (Fig. 3r). At the end of the gastrula stage, the blastoderm covered the yolk (Fig. 3s) and, thus, the closure of the blastopore could be observed $(100 \%$ epiboly) with the formation of the vitelline plug and the differentiation of the cephalic and caudal regions (Fig. 3t).

\section{Segmentation}

This stage was longer than the other stages at the temperatures studies, lasting for $12 \mathrm{~h}, 8 \mathrm{~h}$ and $6 \mathrm{~h} 15$ $\mathrm{m}$ at $22^{\circ} \mathrm{C}, 26^{\circ} \mathrm{C}$, and $30^{\circ} \mathrm{C}$; respectively (Table 1 ).

Organogenesis and histogenesis took place during segmentation, and the tissues and organs differentiated through cellular interaction. It was possible to observe the development of the embryonic axis, and the cephalic and caudal regions (Fig. 4a). The neural groove could be seen when the embryos were analysed dorsally. Characterizing this stage, the first somites (Fig. $4 b)$ were visualized at $12 \mathrm{~h} 30 \mathrm{~min}\left(22^{\circ} \mathrm{C}\right), 8 \mathrm{~h}$ $\left(26^{\circ} \mathrm{C}\right)$, and $5 \mathrm{~h} 45 \mathrm{~min}$ post-fertilization $\left(30^{\circ} \mathrm{C}\right)$.

The morphologic events that occurred during embryo development were similar in the three temperatures analysed; however, the time taken for the structures to appear were different (Table 1). The optic vesicle formed when the embryo had 10 somites (Fig. 4c), the tail began to be released when the embryo reached 18 somites (Fig. 4d), and the primordium of the otic and the Kupffer vesicle were observed with 
(a)

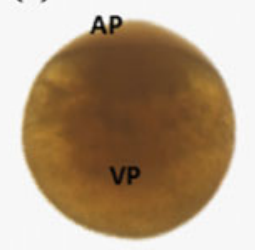

(e)

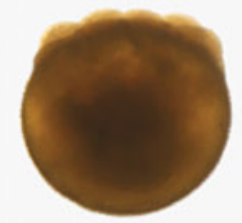

(i)

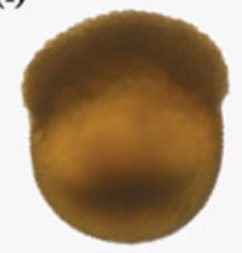

(m)

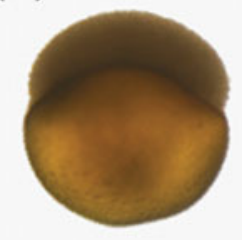

(q)

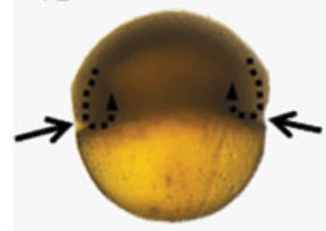

(b)

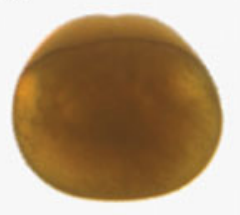

(f)

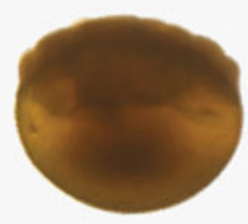

(j)

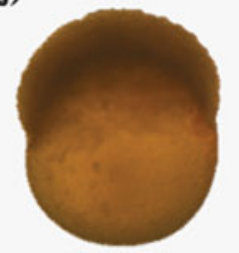

(n)

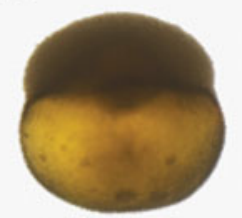

(r)

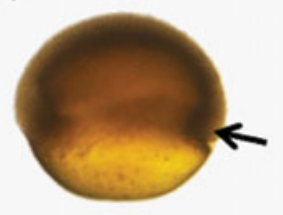

(c)

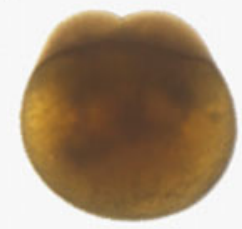

(g)

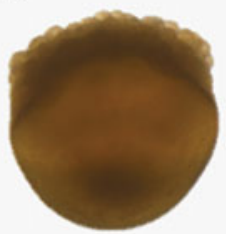

(k)

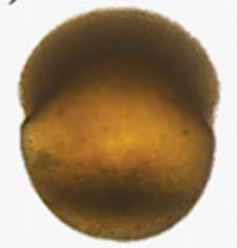

(o)

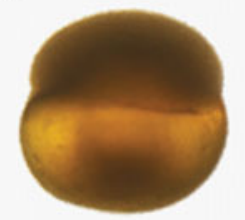

(s)

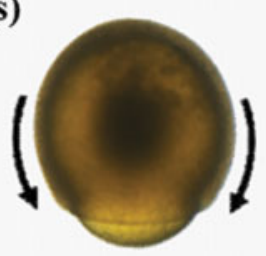

(d)

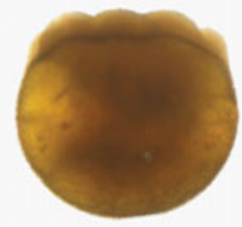

(h)

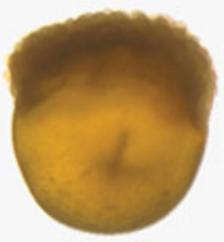

(l)

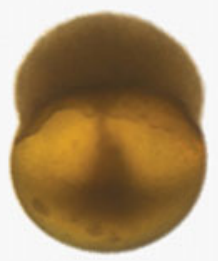

(p)

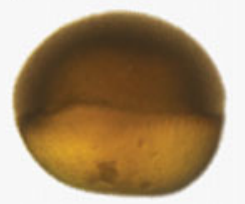

(t)

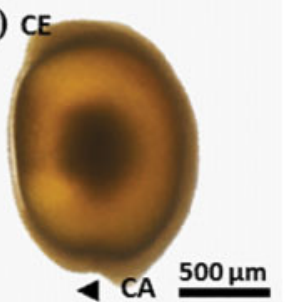

Figure 3 Early embryo development of Brycon amazonicus during the stages of cleavage $(b-g)$, blastula $(h-o)$, and gastrula $(p-t)$. (a) Formation of the blastodisc animal pole (AP) and vegetal pole (VP). (b) 2-cell stage. (c) 4-cell stage. (d) 8-cell stage. (e) 16-cell stage. $(f)$ 32-cell stage. $(g)$ 64-cell stage. $(h)$ 128-cell stage. $(i)$ 256-cell stage. $(j)$ 512-cell stage. $(k) 1 \mathrm{k}$-cell stage. $(l)$ Oblong stage. $(m)$ Sphere stage. $(n)$ Dome stage. $(o)$ 30\% epiboly. $(p)$ 50\% epiboly. $(q)$ cell involution (broken arrows) and germ ring (arrows). ( $r$ ) 80\% epiboly, embryonic shield (arrow). (s) 90\% epiboly, epiboly movement leading to blastopore closure (arrow). $(t) 100 \%$ epiboly, formation of the embryonic axis with differentiation of the cephalic (CE) and caudal regions (CA), blastopore closure (arrowhead).

20 somites (Fig. 4e). In embryos containing 20-26 somites, it was possible to observe an elongated area of the yolk sac, denominated yolk extension (Fig. 4f).

When the embryo reached 26 somites, the notochord primordium could be seen, as well as the start of pericardial cavity development in the area anterior to the yolk sac (Fig. 4f). In embryos with 30 somites, it was possible to observe the development of the structures that comprise the central nervous system (CNS) (Fig. 4g). In embryos with 34-36 somites, the embryonic fin began to develop and the CNS structures began to differentiate into the three 
(a)

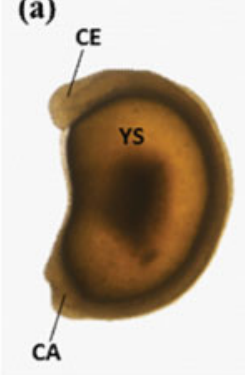

(f)

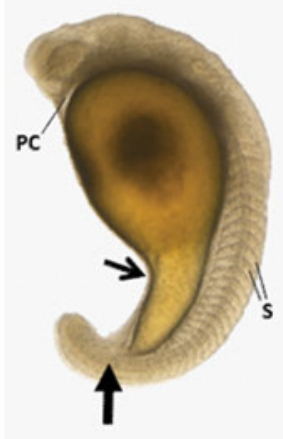

(b)

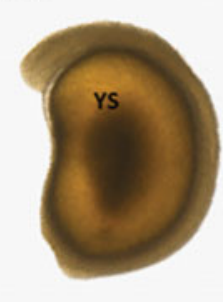

(g) CNS

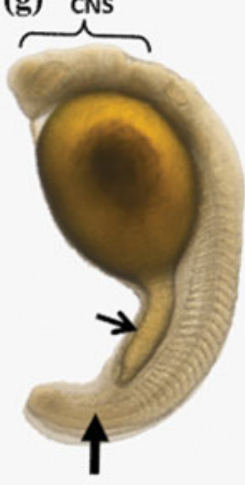

(c) $\mathrm{op}$

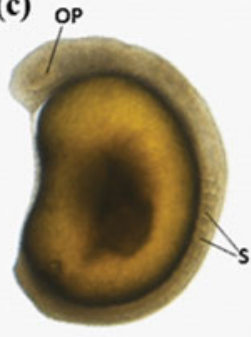

(h)

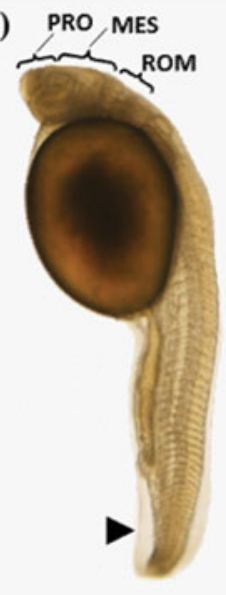

(d)

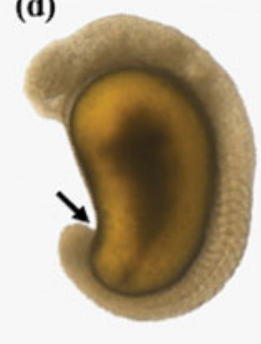

(i)

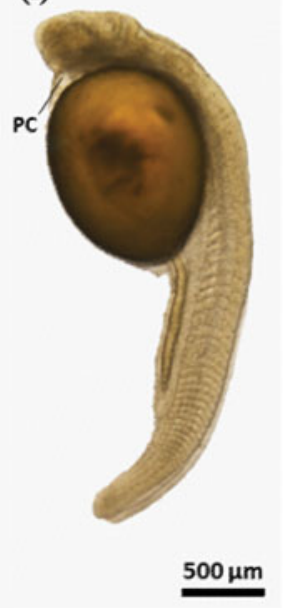

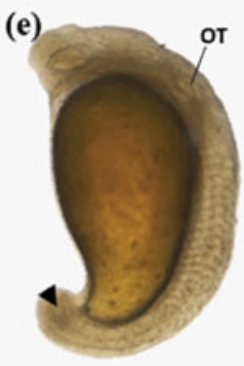

(j)

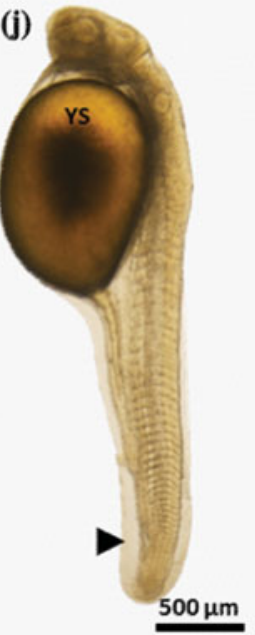

Figure 4 Early embryo development of Brycon amazonicus from segmentation to hatching. (a) Embryo with two somites, yolk sac (YS), and formation of the cephalic (CE) and caudal region (CA). (b) Embryo with four somites, note the size of the yolk sac (YS). (c) Embryo with 10 somites (S) and optic vesicle (OP). (d) Embryo with 18 somites, tail starting the be released (closed arrow). (e) Embryo with 20 somites, otic vesicle (OT), and Kupffer vesicle (arrowhead). (f) Embryo with 26 somites (S), beginning of pericardial cavity development (PC), yolk extension (open arrow), and notochord primordium (closed arrow). ( $g$ ) Embryo with 30 somites, beginning of central nervous system development (CNS), notochord primordium (closed arrow); note the evident reduction in the yolk extension (open arrow). (h) Embryo with 36 somites, differentiation of the central nervous system regions (CNS): prosencephalon (PRO), mesencephalon (MES), and rhombencephalon (ROM); note the presence of embryonic fin (arrowhead) around the tail. (i) Embryo with 38 somites; note the presence of the pericardial cavity (PC). (j) Newly hatched larva with 44 somites and distended posture, ellipsoid yolk sac (YS), embryonic fin (arrowhead), absence of body pigmentation.

primary vesicles: prosencephalon (PRO), mesencephalon (MES), and rhombencephalon (ROM) (Fig. 4h). The yolk extension was almost completely absorbed during the segmentation phase as a consequence of tissue and organ development (Fig. 4i).

The elongation of the embryo, with height consequently greater than width (Fig. 5), and the progressive increase in the number of somites, which occurred at different times at the temperatures tested (Fig. 6), culminated in the formation of the tail.

The embryos maintained similar patterns of height and width when compared at the same stages of development at the three different temperatures, as illustrated in Fig. 5, and each stage had specific measures due to cleavage and/or cell movements.

\section{Hatching and larval development}

The rupture of the chorion by the larvae characterized the time of hatching. Normal newly hatched larvae were transparent; had a distended posture; closed mouth and anus; unpigmented eyes, in which only the optical cup and the crystalline could be identified; well delimitated otic vesicle lacking pigmentation; and embryonic fin covering the whole caudal region (Fig. 4j). The head was positioned ventrally and adhered to the anterior portion of the yolk sac, which was ellipsoid (Figs $4 j$ and $7 a$ ). It was also possible to visualize the epiphysis (pineal gland) at the frontal region of the head.

Hatching time varied with temperature and occurred earliest at $30^{\circ} \mathrm{C}(11 \mathrm{~h} 30 \mathrm{mpf})$ and latest at $22^{\circ} \mathrm{C}$ (24 h $30 \mathrm{mpf}$ ) (Table 1). However, no significant 
difference $(P>0.05)$ was observed in the hatching rate or in the rate of normal and abnormal larvae between the temperatures tested (Table 3).

The number of somites of the newly hatched larvae varied between the three incubation temperatures (34, 38 , and 44 somites at 22,26 , and $30^{\circ} \mathrm{C}$; respectively) (Fig. 6); however, there was no significant difference $(P>0.05)$ in total larval length between the groups $\left(3.49 \pm 0.04 \mathrm{~mm}\right.$ at $22^{\circ} \mathrm{C}, 3.67 \pm 0.05 \mathrm{~mm}$ at $26^{\circ} \mathrm{C}$, and $3.58 \pm 0.04 \mathrm{~mm}$ at $30^{\circ} \mathrm{C}$ ).

After hatching, it was possible to record the development of the eyes and their pigmentation, branchial arches, heart, primitive gut, opening of the mouth and anus, and a noticeable reduction in the size of the yolk sac. The development of the structures mentioned above occurred at different times for each temperature studied (see Table 2).

The CNS was better developed after hatching; however, the structures were not well delineated (Fig. $7 b$ ). Eye pigmentation began in the optic cup, the mouth began to form as a groove on the head close to the area anterior to the yolk sac (Fig. 7c), and the primitive gut was observed as a long and straight tube that terminated at the anal opening (anus) (Fig. $7 d$ ). The pericardial cavity was clearly visible, located anterior to the yolk sac (Fig. 7e). The heart primordium, denominated cardiac tube, appeared as a simple circular structure in the pericardial cavity, and the mouth could be found open (Fig. 7f).

The head moved from ventral to semi-ventral position. The CNS regions began to differentiate, as well as the three primary vesicles: the prosencephalon (PRO) subdivided into telencephalon $(\mathrm{T})$ and diencephalon (D), the mesencephalon (MES) and rhombencephalon (ROM) subdivided into metencephalon (ME) and myelencephalon (MI), and the epiphysis (pineal gland) appeared as a salience in the anterior region of the head (Fig. $7 g$ ). Some structures that composed the cephalic region could be distinguished when the larvae were observed dorsally; such as the olfactory bulb, cerebral hemispheres, epiphysis located between the cerebral hemispheres, evident optic lobule, rhombencephalon composed by the metencephalon (precursor to the cerebellum) and myelencephalon (precursor to the bulb) (Fig. $7 h$ ), which continued caudally with the spinal cord.

During larval development, the heart contained one atrium and one ventricle, eye pigmentation became more intense (Fig. 7i), blood was light red and could be observed inside the atrium, the sinus venosus was present (Fig. $7 i, j$ ) and could be seen as a narrow canal through which blood would flow to the atrium. Lastly, the head was observed at is final position (terminal), the mouth and anus were open, and there was a marked reduction in the yolk sac (Fig. 7k). 
(a)

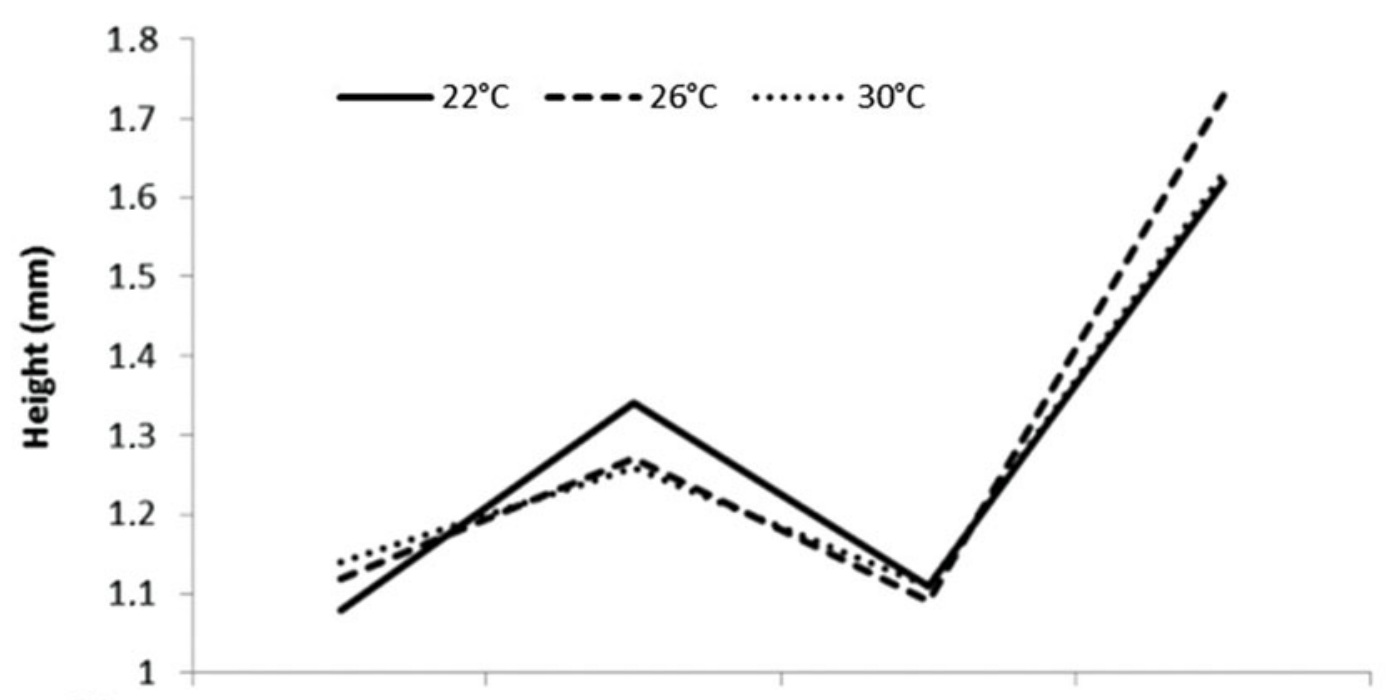

(b)

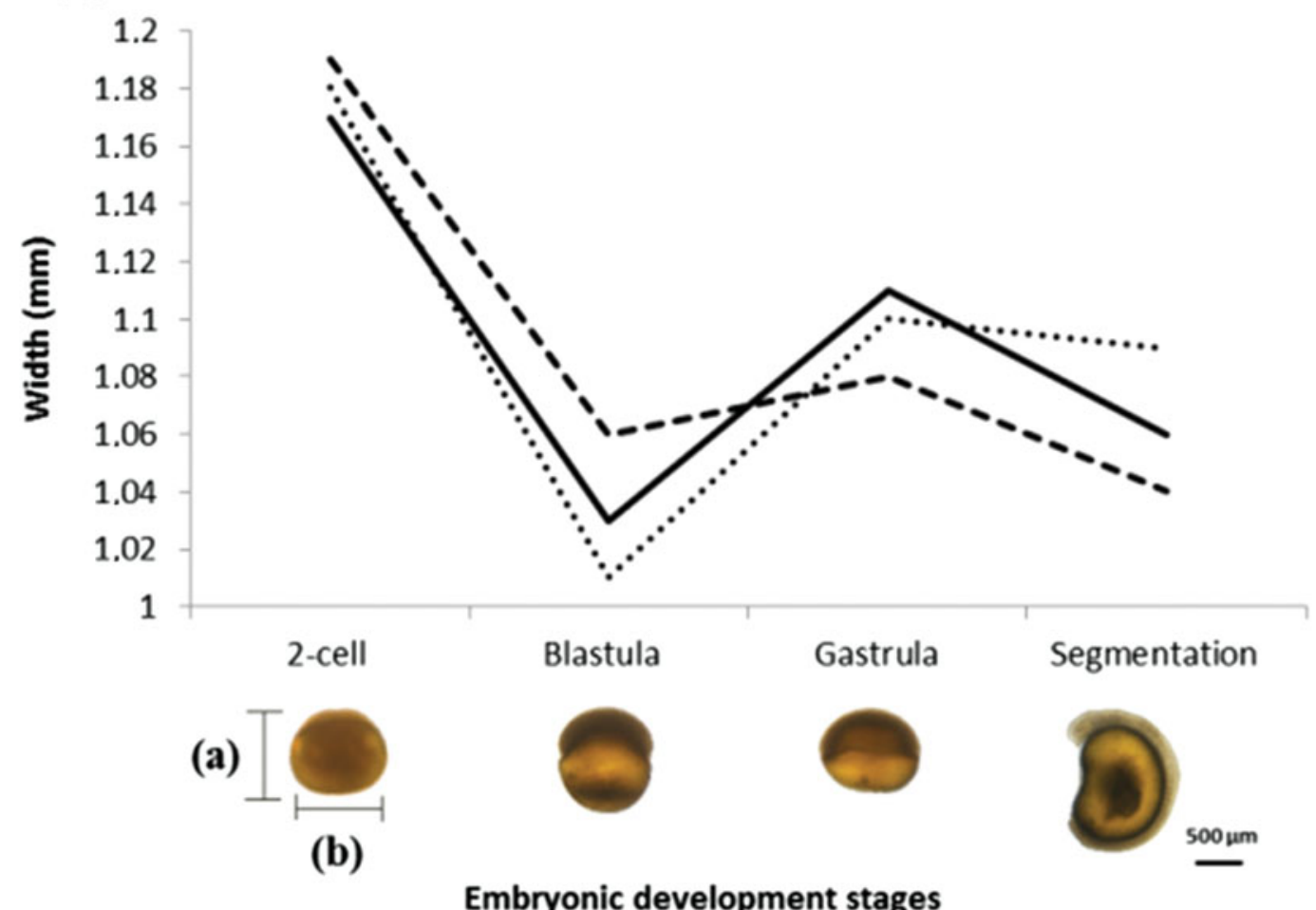

Figure 5 Mean width and height in millimetres $(\mathrm{mm})$ of the eggs and embryos of $B$. amazonicus incubated at $22^{\circ} \mathrm{C}, 26^{\circ} \mathrm{C}$, and $30^{\circ} \mathrm{C}$. (a) Height. (b) Width. The height and width measurements are detailed in the figures bellow the graph.

Larvae were considered abnormal when the head, tail, and/or yolk sac were poorly formed; impairing the larvae swimming ability. The main deformities observed were related to malformation of the CNS (cephalic region), spinal cord, heart, and yolk sac. Heart malformations were observed with greater frequency in larvae incubated at $30^{\circ} \mathrm{C}$. However, in all three temperatures, the larvae showed increased heart volume and deformed cardiac structure (Fig. $8 a$, $\left.a^{\prime}\right)$; malformation of the tail, which was short or flexed (Fig. 8b, d); enlarged pericardial cavity; yolk extravasation at the yolk extension (Fig. 8c); deformed head; microcephaly (reduced or absent cephalic regions) (Fig. $8 d$ ); bent body (Fig. 8e); lordosis (Fig. 8g); or scoliosis. These deformities were observed in embryos at the final stage of segmentation (close to 


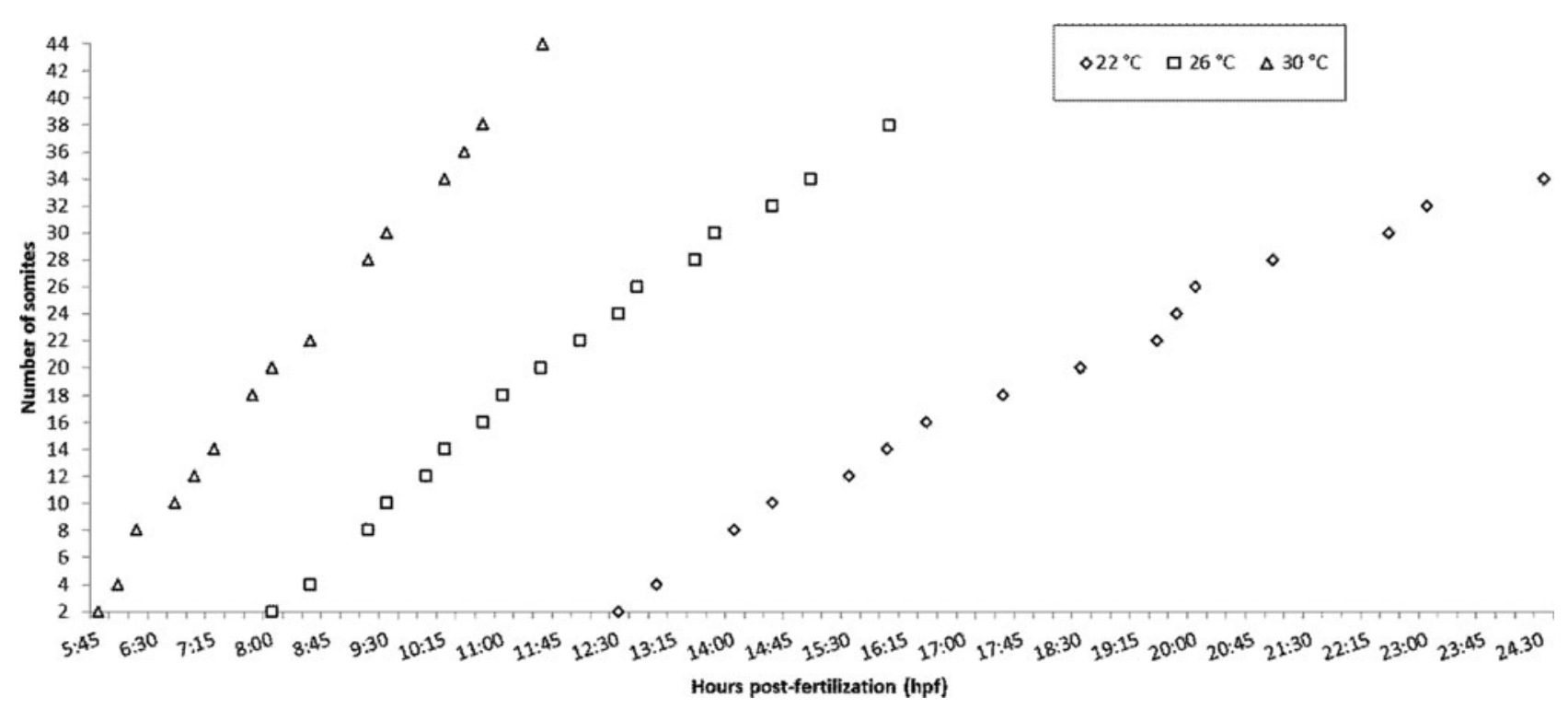

Figure 6 Progressive number of somites, from segmentation to hatching, in embryos of B. amazonicus incubated at $22^{\circ} \mathrm{C}, 26^{\circ} \mathrm{C}$, and $30^{\circ} \mathrm{C}$.

hatching), which probably led to their death prior to hatching as they were unable to move adequately and rupture the chorion. The larvae that hatched with head deformities, such as microcephaly, died within $\mathrm{h}$ of hatching.

\section{Discussion}

The results from this study have demonstrated that the duration of the stages of early development in $B$. amazonicus is strongly affected by incubation temperature, occurring slower at $22^{\circ} \mathrm{C}$ and faster at $30^{\circ} \mathrm{C}$. This data corroborate the findings by Ninhaus-Silveira et al. (2006), who stated that the duration of embryogenesis depends on the temperature, being longer at lower and shorter at higher temperatures.

The knowledge of the early development stages in $B$. amazonicus at the temperatures tested can be applied to species of the same genus, as the development pattern observed in this study was similar to that described for embryonic and larval development in other species, such as B. cephalus Günther, 1869 (Romagosa et al., 2001; Alexandre et al., 2009); B. insignis Steindachner, 1877 (Andrade-Talmelli et al., 2001; Isaú et al., 2013); B. guatemalensis Regan, 1908 (Molina-Arias, 2006); B. orbignyanus Valenciennes, 1850 (Nogueira et al., 2014; Reynalte-Tataje et al., 2004); B. gouldingi Lima, 2004 (Faustino et al., 2011, 2015); B. orthotaenia Günther, 1864 (Gomes et al., 2013); and B. hilarii Valenciennes, 1850 (Oliveira et al., 2012). Therefore, it is possible to use the different temperatures to manipulate embryos by accelerating or slowing the stages of development, thus enabling the use of cellular micromanipulation technique.

Karyogamy ensures the genetic diversity of the offspring (Fukuda et al., 2015) and, in the present study, occurred a few min after fertilization (6 mpf at $30^{\circ} \mathrm{C}$, and $8 \mathrm{mpf}$ at 22 and $26^{\circ} \mathrm{C}$ ). Pereira-Santos et al. (2016) reported that in A. altiparanae the fusion of the pronuclei was observed between 8-10 mpf. However, Zhang et al. (2015) reported that in Carassius gibelio this fusion occurred between 10 and $30 \mathrm{mpf}$ in eggs kept at $23^{\circ} \mathrm{C}$. These findings demonstrate that the biological processes occur slower in eggs incubated at lower temperatures, highlighting the influence of temperature soon after fertilization.

During cleavage, the blastomeres in B. amazonicus increased in number and decreased in size. Some authors have reported that this event, characterized by a reduction in cell size, is a result of the nontranscription of the zygote genome and, thus, the cells undergo mitotic division inheriting maternal mRNA and cytoplasm produced during oogenesis (Andéol, 1994; Alberts et al., 2004). The occurrence of this phenomenon is independent of temperature but the speed in which it takes place is (Martell et al., 2005), in agreement with the data from the present study.

The effects of temperature were very evident during the stages of blastula, gastrula, and segmentation in $B$. amazonicus, with a wide variation in the duration of the 512-1000 blastomeres phase at different temperatures; which lasted $25 \mathrm{~min}$ at 26 and $30^{\circ} \mathrm{C}$, a relatively short period for cell micromanipulation. However, in eggs incubated at $22^{\circ} \mathrm{C}$, these phases lasted for $1 \mathrm{~h} 30 \mathrm{~min}$; as similarly reported in cold-water teleostei such as Misgurnus anguillicaudataus and Tinca, in which these 
(a)

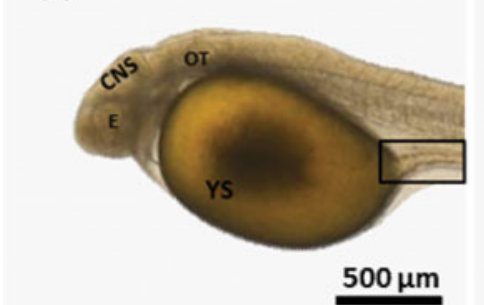

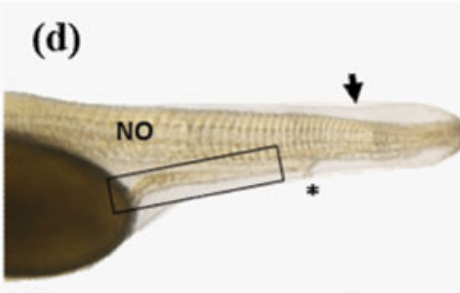
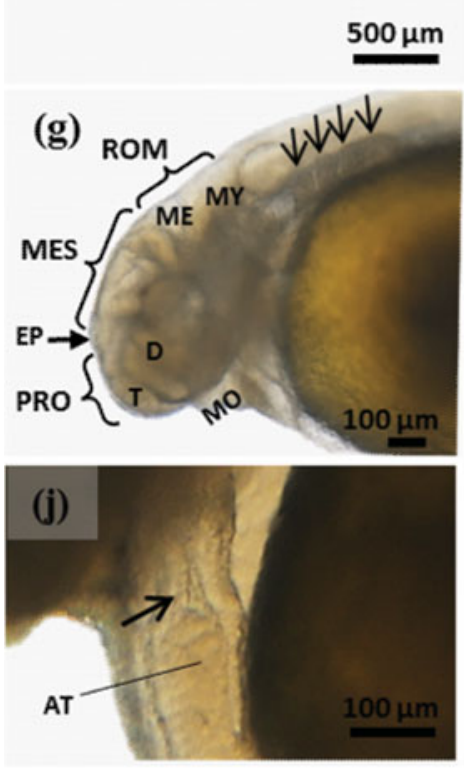

(e)
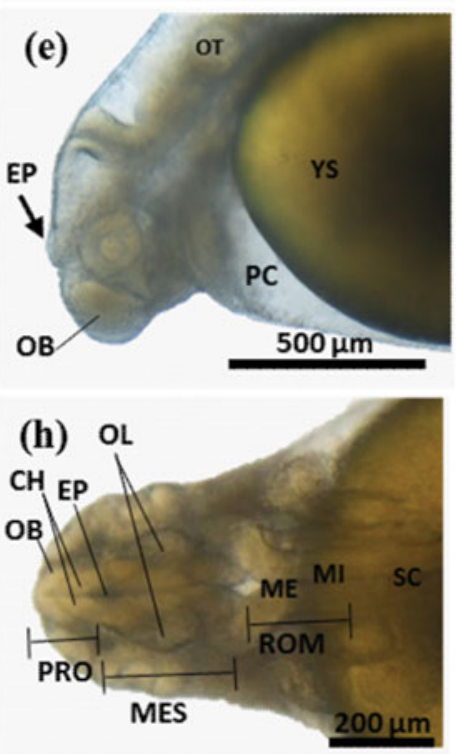

(b)

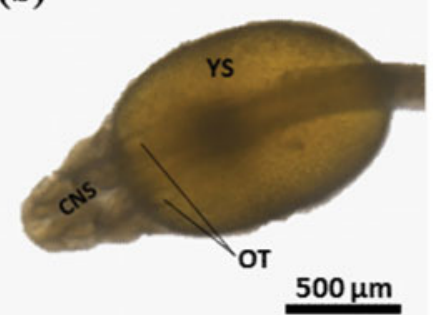

(c)
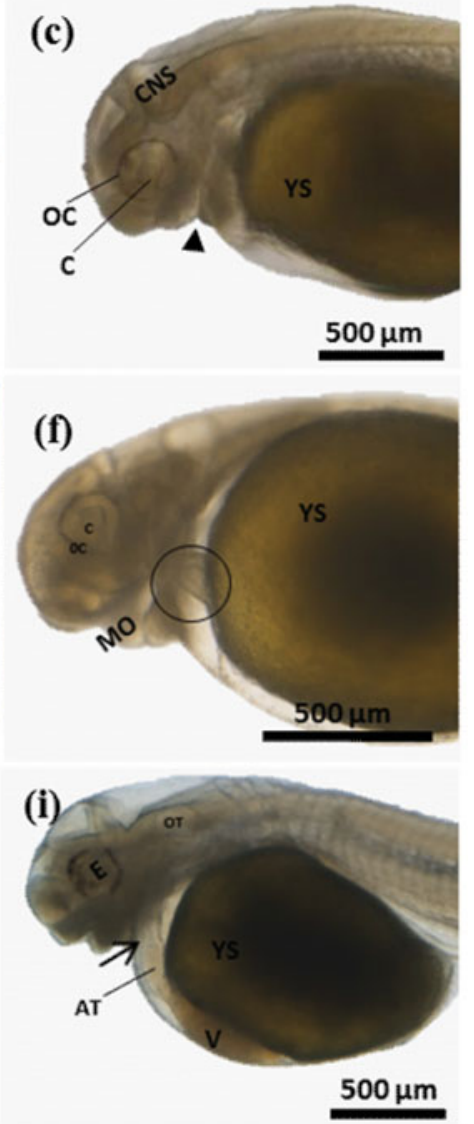

(k)

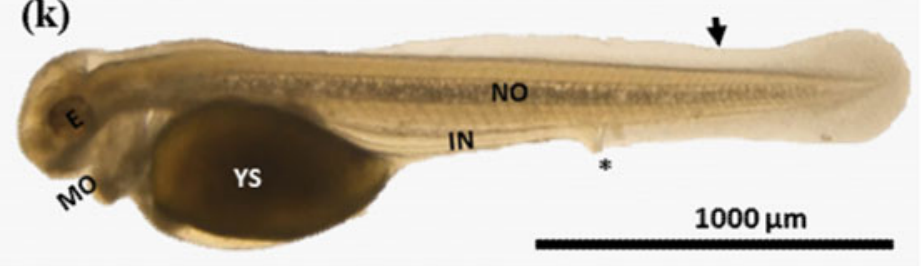

Figure 7 Normal larval development in Brycon amazonicus after hatching. (a) Newly hatched larvae with unpigmented eye (E), otic vesicle (OT), developing central nervous system (CNS), and ellipsoid yolk sac (YS) with yolk extension (detail). (b) Dorsal view, otic vesicle (OT) and central nervous system (CNS). (c) Eye pigmentation (E) around the optic cup (OC), crystalline (C), beginning of mouth development (arrowhead) close to the anterior region of the yolk sac (YS). (d) Notochord (NO), embryonic membrane (arrow), primitive gut (detail), and developing anal opening $\left(^{*}\right)$. (e) Olfactory bulb (OB), otic vesicle (OT), epiphysis (EP) (arrow), and pericardial cavity (PC). (f) Mouth (MO); optic cup (OC); crystalline (C); and developing heart, denominated cardiac tube (detail). ( $g$ ) Branchial arches (open arrows), epiphysis (EP) (arrow), three primary vesicles that compose the central nervous system (CNS) prosencephalon (PRO) subdivided into telencephalon (T) and diencephalon (D), mesencephalon (MES) and rhombencephalon (ROM) subdivided into metencephalon (ME) and myelencephalon (MY). ( $h$ ) Dorsal view of the cephalic region, epiphysis (EP), prosencephalon (PRO) composed of olfactory bulb (OB) and cerebral hemispheres $(\mathrm{CH})$, mesencephalon (MES) composed by optic lobule (OL), rhombencephalon (ROM) composed by metencephalon (precursor to the cerebellum) and myelencephalon (precursor to the bulb), spinal cord (SC). (i) Eye (E) with intense pigmentation, otic vesicle (OT), yolk sac (YS), heart composed by atrium (AT) and ventricle (V); note the sinus venosus (narrow arrow). ( $j$ ) Heart detailing the sinus venosus (arrow) and atrium (AT). ( $k$ ) Normal larvae at $22 \mathrm{hpf}$ at $30^{\circ} \mathrm{C}$, open mouth (MO), pigmented eye (E), notochord (NO), well developed embryonic membrane (arrow), well delimited primitive gut (IN), and anal opening $\left(^{*}\right)$.

phases lasted $1 \mathrm{~h} 20 \mathrm{~min}$ at $20^{\circ} \mathrm{C}$ (Fujimoto et al., 2006; Linhartova et al., 2014). According to Fraser et al. (2014), temperature has a significant effect on fish ontogeny and, as such, is often manipulated to regulate the incubation time in farmed fish. In the present study, it was possible to increase the time available for micromanipulation, enabling cell transplant to be carried out in a greater number of embryos. 

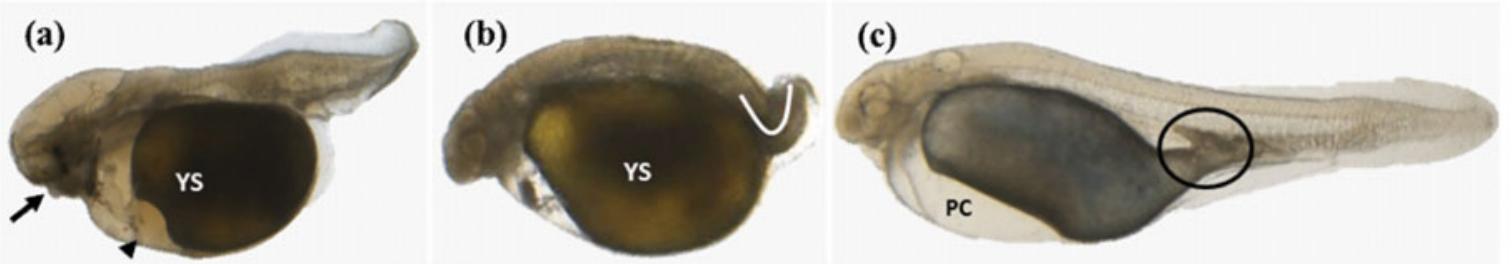

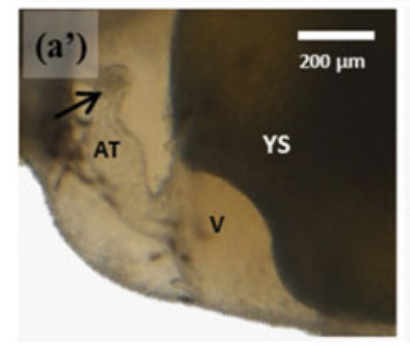

(f)
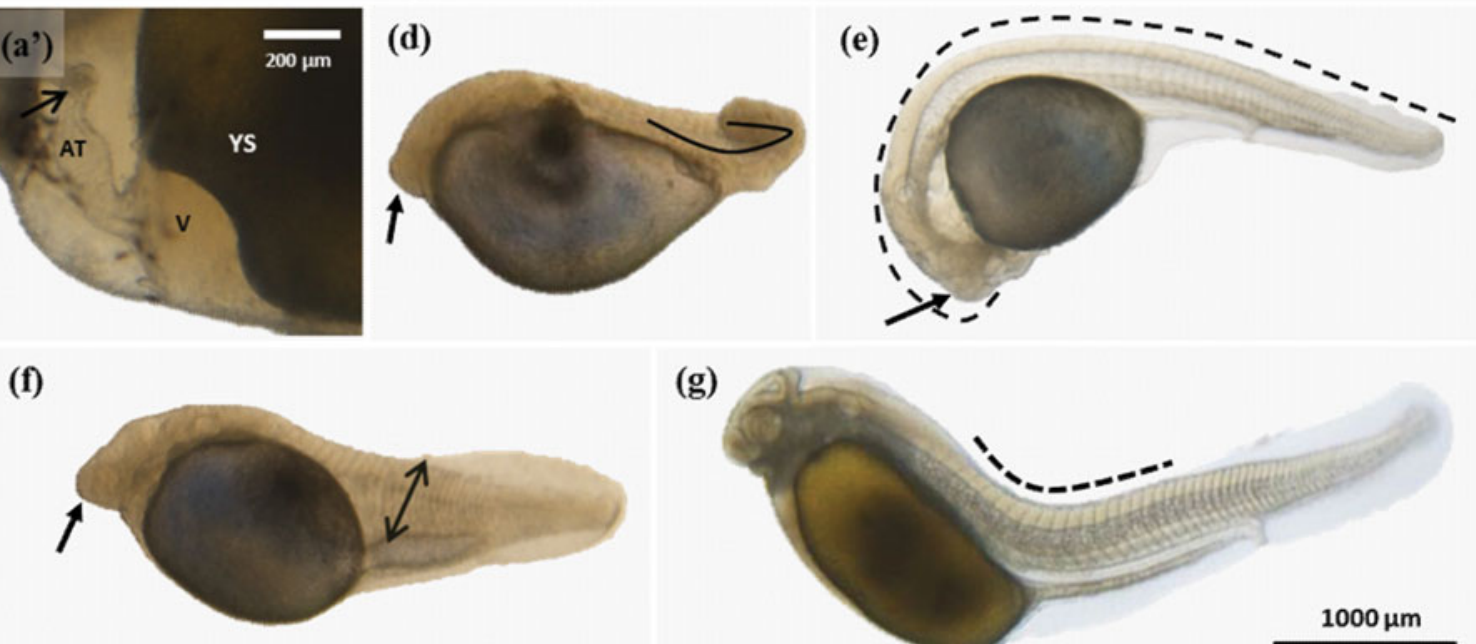

(g)

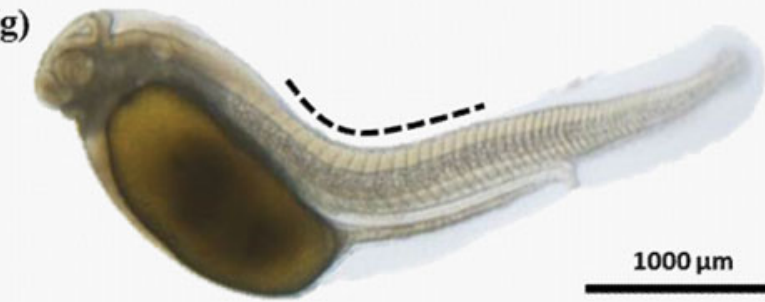

Figure 8 Newly hatched morphologically abnormal larvae of Brycon amazonicus. (a) Head (closed arrow) and deformed heart (arrowhead); note the malformation of the tail making it short. (a') Deformed heart; note the irregularity of the cardiac structures, sinus venosus (open arrow), atrium (AT), and ventricle (V). (b) Short tail and deformed yolk sac (YS). (c) Pericardial cavity (PC) visibly enlarged and consequently deformed yolk sac; extravasating yolk extension (detail). (d) Microcephaly (arrow) and flexed tail. (e) Deformed head (arrow), curved body (broken line). (f) Microcephaly (arrow) and non-uniform somites (double-headed arrow). ( $g$ ) Non-linear body, tail flexed upwards (dotted line indicates area of malformation).

The hatching rates in B. amazonicus were greater than $65 \%$ at the three temperatures tested and the rates of abnormal larvae (deformed) were similar to those reported by Pereira-Santos et al. (2016) in Astyanax altiparanae under the same temperatures. Abdel et al. (2004) reported that fish anomalies can be associated to temperature, as it was observed that the acceleration of embryonic and larval development due to an increase in temperature resulted in malformations and increased the mortality rate in European seabass (Dicentrarchus labrax). Furthermore, incubation temperature is considered as one of the major factors affecting embryo and larval development.

It has been suggested that sub-optimum temperatures can increase the occurrence of morphological alterations and reduce larval survival (Bermudes \& Ritar, 1999; Hansen \& Falk-Petersen, 2002; Martell et al., 2005). This was observed in the present study and similar results have been reported by RodriguesGaldino et al. (2009) in Rhamdia quelen incubated at 21, 24,27 , or $30^{\circ} \mathrm{C}$. These authors further reported that $R$. quelen kept at $30^{\circ} \mathrm{C}$ developed heart oedema, similarly to the observed in the present study in B. amazonicus kept at the same temperature. Uji et al. (2014) reported that other intrinsic factors, besides temperature, can influence deformity rates, such as egg quality and genetic factors.

In the present study, recently hatched larvae showed different number of somites at each temperature, with greater number of somites being observed at higher temperatures (from 34 to 44 somites at $22^{\circ} \mathrm{C}$ and $30^{\circ} \mathrm{C}$, respectively); however, there was no significant difference in total larval length between the temperatures tested. Gomez \& Pourquié (2009) reported that the balance between the speed of somatogenesis and that of the elongation of the embryonic axis influences the size of the embryos and the number of somites. If the speed of somatogenesis is greater than that of the elongation of the axis, there will be a greater number of somites within a limited space; which in turn restricts the size of the somites. On the other hand, if the speed of axis elongation is greater or similar to that of somatogenesis, the size of the somites will increase or remain unchanged. However, the number of somites in newly hatched larvae is often species specific (Fujimoto et al., 2006), in agreement with Arakawa et al. (1999) who reported 36 somites in ice goby kept at $19^{\circ} \mathrm{C}$, and 30 and 34 somites in zebrafish at $28.5^{\circ} \mathrm{C}$. 
Most teleostei fish at the time of hatching do not have fully functional systems due to their degree of differentiation (Nakatani et al., 2001), as observed in this study in B. amazonicus. After hatching, the morphogenesis of several rudimentary organs, including mouth, heart, and gut is completed and occurs rapidly at $30^{\circ} \mathrm{C}$. However, some of these structures become hard to visualize in the larvae, due to their position deep within the body, and thus it is easier to observe the reduction of the yolk sac; and the development of fins, mandibles, and vascular network. During the larval period, the larva gradually begins to swim and move its mandibles, branchiae, fins, and eyes. Kimmel et al. (1995) suggested that the development of these structures result in quick flight response, breathing, hunting, and feeding. However, in the present study, it was not possible to visualize these structures in larvae kept at $22^{\circ} \mathrm{C}$ due to the delay in development as a consequence of temperature; demonstrating that at $30^{\circ} \mathrm{C}$, the accelerated development makes the larvae morphologically more developed.

Understanding the effects of temperature on the ontogeny of the species of interest enables the manipulation of the ontogenic pattern, allowing for specific stages of development to last longer so that new biotechnology techniques, such as cellular micromanipulation, can be applied to produce chimera fish of commercial interest to aquaculture and aid in the rearing of fish during the early stages of life.

In conclusion, temperature directly affects the duration of the stages of embryonic and larval development, influencing hatching time and organ differentiation, which occurred faster at $30^{\circ} \mathrm{C}$ and slower at $22^{\circ} \mathrm{C}$. Embryos maintained at $22^{\circ} \mathrm{C}$ showed longer lasting phases, making it possible to increase the number of transplanted embryos. Nevertheless, all temperatures tested were viable for the development of B. amazonicus.

\section{Acknowledgements}

The authors would like to thank the National Centre for Research and Continental Fish Conservation, Chico Mendes Institute of Biodiversity Conservation (CEPTA/ICMBio) Pirassununga-SP; and the UNESP's Aquaculture Centre (CAUNESP), Jaboticabal-SP, Brazil.

\section{Financial support}

This research was supported by CNPq (grant numbers 140633/2013-8, PhD scholarship) and FAPESP (grant numbers 2010/17429-1, JP FAPESP).

\section{Ethical standards}

The authors assert that all procedures contributing to this work comply with the ethical standards of the relevant national and institutional guides on the care and use of laboratory animals. The animals collected was realized in accordance with the procedure approved by the by the Ethics Committee in the Use of Animals of the Universidade Estadual Paulista (UNESP), Jaboticabal-SP, Brazil (protocol number 018413/13).

\section{References}

Abdel, I., Abellán, E., López-Albors, O., Valdés, P., Nortes, M. \& García-Alcázar, A. (2004). Abnormalities in the juvenile stage of sea bass (Dicentrarchus labrax L.) reared at different temperatures: types, prevalence and effect on growth. Aquac. Int. 12, 523-38.

Alberts, B., Johnson, A., Lewis, J., Raff, M., Roberts, K. \& Walter, P. (2004). Biologia Molecular da Célula, Artmed, Porto Alegre.

Alexandre, J.S., Ninhaus-Silveira, A., Veríssimo-Silveira, R., Buzollo, H., Senhorini, J.A. \& Chaguri, M.P. (2009). Structural analysis of the embryonic development in Brycon cephalus (Gunther, 1869). Zygote 18, 173-83.

Andéol, Y. (1994). Early transcription in different animal species: implication for transition from maternal to zygotic control in development. Roux Arch. Dev. Biol. 204, 3-10.

Andrade-Talmelli, E. F., Kavamoto, E. T., Romagosa, E. \& Fenerich-Verani, N. (2001). Embryonic and larval development of the 'Piabanha', Brycon insignis, STEINDACHNER, 1876 (Pisces, Characidae). Boletim do Instituto de Pesca 27, 21-8.

Arakawa, T., Kanno, Y., Akiyama, N., Kitano, T., Nakatsuji, N. \& Nakatsuji, T. (1999). Stages of embryonic development of the ice goby (shiro-uo), Leucopsarion petersii. Zoo. Sci. 16, 761-73.

Bermudes, M. \& Ritar, A.J. (1999). Effects of temperature on the embryonic development of the striped trumpeter (Latris lineata Bloch and Schneider, 1801). Aquaculture 176, 245-55.

Camargo, A.C.S., Zaiden, S.F. \& Urbinati, E.C. (2008). Desenvolvimento gonadal de fêmeas de matrinxã, Brycon amazonicus, submetidas a restrição alimentar. Ciência Rural 38, 1105-10.

Faustino, F., Makino, L. C., Neumann, E. \& Nakaghi, L.S.O. (2015). Morphological and morphometric aspects of early life stagesof piabanha Brycon gouldingi (Characidae). J. Fish Biol., 86, 1491-506.

Faustino, F., Nakaghi, L.S. O., Marques, C., Ganeco, L.N. \& Makino, L.C. (2010). Structural and ultrastructural characterization of the embryonic development of Pseudoplatystoma spp. hybrids. Int. J. Dev. Biol., 54, 723-30.

Faustino, F., Nakaghi, L.S.O. \& Neumann, E. (2011). Brycon gouldingi (Teleostei, Characidae): aspects of the embryonic development in a new fish species with aquaculture potential. Zygote 19, 351-63. 
Fraser, T.W. K., Fleming, M. S., Poppe, T. T., Hansen, T. \& Fjelldal, P.G. (2014). The effect of ploidy and incubation temperature on survival and the prevalence of aplasia of the septum transversum in Atlantic salmon, Salmo salar $L$. J. Fish Dis. 37, 189-200.

Fujimoto, T., Kataoka, T., Otani, S., Saito, T., Aita, T., Yamaha, E. \& Arai, K. (2004). Embryonic stages from cleavage to gastrula in the loach Misgurnus anguillicaudatus. Zoo. Sci. 21, 747-55.

Fujimoto, T., Kataoka, T., Sakao, S., Saito, T., Yamaha, E. \& Arai, K. (2006). Dev. Stages and Germ Cell Lineage of the Loach (Misgurnus anguillicaudatus). Zoo. Sci. 23, 977-89.

Fukuda, Y., Akematsu, T., Attiq, R., Tada, C., Nakai, Y. \& Pearlman, R.E. (2015). Role of the Cytosolic Heat Shock Protein 70 Ssa5 in the Ciliate Protozoan Tetrahymena thermophila. J. Eukaryot. Microbiol. 62, 481-93.

Gomes, L.C. \& Urbinati, E.C. (2005). Matrinxã (Brycon amazonicus). In Espécies Nativas para Piscicultura no Brasil (ed. UFSM) Santa Maria, pp. 149-64.

Gomes, R. Z., Sato, Y., Rizzo, E. \& Bazzoli, N. (2013). Early development of Brycon orthotaenia (Pisces: Characidae). Zygote 21, 11-20.

Gomez, C. \& Pourquié, O. (2009). Dev. control of segment numbers in vertebrates. J. Exp. Zool. B: Mol. Dev. Evol. 312, 533-44.

Hansen, T.K. \& Falk-Petersen, I.B. (2002). Growth and survival of first-feeding spotted wolffish (Anarhichas minor Olafsen) at various temperature regimes. Aquac Res. 33, 1119-27.

Howes, G. (1982). Review of the genus Brycon (Teleostei: Characoidei). Bull. Br. Mus. (Nat. Hist.) Zool. 43, 1-47.

Isaú, Z. A., Rizzo, E., Amaral, T. B., Mourad, N. \& Viveiros, A. (2013). Structural analysis of oocytes, post-fertilization events and embryonic development of the Brazilian endangered teleost Brycon insignis (Characiformes). Zygote 21, 85-94.

Kimmel, C. B., Ballard, W. W., Kimmel, S. R., Ullmann, B. \& Schilling, T.F. (1995). Stages of embryonic development of the zebrafish. Dev. Dynam. 203, 253-310.

Lima, F.C.T. \& Castro, R.M.C. (2000). Brycon vermelha, a new species of characid fish from the Rio Mucuri, a coastal river of eastern Brazil (Ostariophysi: Characiformes). Ichthyol. Explor. Freshw. 11, 155-62.

Linhartova, Z., Saito, T. \& Psenicka, M. (2014). Embryogenesis, visualization and migration of primordial germ cells in tench (Tinca tinca). J. Appl. Ichthyol. 30, 29-39.

Martell, D. J., Kieffer, J.D. \& Trippel, E.A. (2005). Effects of temperature during early life history on embryonic and larval development and growth in haddock. J. Fish Biol., 66, 1558-75.

Melamed, P., Gong, Z., Fletcher, G. \& Hew, C.L. (2002). The potential effect of modern biotechnology on fish aquaculture. Aquaculture 204, 255-69.

Molina-Arias, A. (2006). Desarrollo larval de Brycon guatemalensis (Regan, 1908) (Pisces: Characidae). Brenesia 66, 31-6.

Nakagawa, M., Kobayashi, T. \& Ueno, K. (2002). Production of germline chimera in loach (Misgurnus anguillicaudatus) and proposal of new method for preservation of endangered fish species. J. Exp. Zool., 293, 624-31.
Nakaghi, L.S. O., Neumann, E., Faustino, F., Mendes, J.M.R. \& Braga, F.M. (2013). Moments of induced spawning and embryonic development of Brycon amazonicus (Teleostei, Characidae). Zygote 22, 549-57.

Nakatani, K., Agostinho, A. A., Baumgartner, G., Bialetzki, A., Sanches, P.V. \& Cavicchioli, M. (2001). Ovos e larvas de Peixes de Água Doce: Desenvolvimento e Manual de identificação, Eduem/Nupélia, Maringá.

Nakauth, A.C.S.S., Villacorta-Correa, M. A., Chim Figueiredo, M.R. \& Bernardino, G. (2015). Desenvolvimento Embrionário e larval do Brycon amazonicus (GUNTER, 1869). IGAPÓ-Revista de Educação Ciência e Tecnologia do IFAM, 5.

Ninhaus-Silveira, A., Foresti, F. \& Azevedo, A. (2006). Structural and ultrastructural analysis of embryonic development of Prochilodus lineatus (Valenciennes, 1836) (Characiforme; Prochilodontidae). Zygote 14, 217-29.

Nogueira, L. B., Godinho, A.L. \& Godinho, H.P. (2014). Early development and allometric growth in hatchery-reared characin Brycon orbignyanus. Aquac Res., 45, 1004-11.

Oliveira, F. G., Bialetzki, A., Gomes, L. C., Santin, M. \& Taguti, T.L. (2012). Larval development of Brycon hilarii (Characiformes, Characidae). Iheringia. Série Zoologia 102, 62-70.

Pankhurst, N.W. \& Munday, P.L. (2011). Effects of climate change on fish reproduction and early life history stages. Mar. Freshw. Res., 62, 1015-26.

Pereira-Santos, M., Yasui, G.S., Xavier, P.L. P., Admov, N.S. M., Nascimento, N. F., Fujimoto, T., Senhorini, J.A. \& Nakaghi, L.S.O. (2016). Morphology of gametes, postfertilization events and the effect of temperature on the embryonic development of Astyanax altiparanae (Teleostei, Characidae). Zygote 1-3.

Reynalte-Tataje, D., Zaniboni-Filho, E. \& Esquivel, J.R. (2004). Embryonic and larvae development of piracanjuba, Brycon orbignyanus Valenciennes, 1849 (Pisces, Characidae). Acta Scientiarum 26, 5.

Rodrigues-Galdino, A. M., Maiolino, C. V., Forgati, M., Donatti, L., Mikos, J. D., Carneiro, P.C.F. \& Rios, F.S.A. (2009). Dev. of the neotropical catfish Rhamdia quelen (Siluriformes, Heptapteridae) incubated in different temperature regimes. Zygote 18, 131-44.

Romagosa, E., Narahara, M.Y. \& Fenerich-Verani, N. (2001). Stages of embryonic development of the' Matrinxã', Brycon cephalus (Pisces, Characidae). Boletim do Instituto de Pesca, 27, 27-32.

Uji, S., Suzuki, T., Iwasaki, T., Teruya, K., Hirasawa, K., Shirakashi, M., Onoue, S., Yamashita, Y., Tsuji, M. \& Tsuchihashi, Y. (2014). Effect of temperature, hypoxia and disinfection with ozonated seawater during somatogenesis on muscular development of the trunk in larval seven-band grouper, Epinephelus septemfasciatus Aquac Res., 46, 1-9.

Zhang, J., Sun, M., Zhou, L., Li, Z., Liu, Z., Li, X.-Y., Liu, X.-L., Liu, W. \& Gui, J.-F. (2015) Meiosis completion and various sperm responses lead to unisexual and sexual reproduction modes in one clone of polyploid Carassius gibelio. Sci Rep. 5, 1-14. 